\title{
Trophic ecology of Atlantic cod Gadus morhua on the northeast US continental shelf
}

\author{
Jason S. Link* ${ }^{*}$ Lance P. Garrison \\ Food Web Dynamics Program, Northeast Fisheries Science Center, National Marine Fisheries Service, 166 Water St., \\ Woods Hole, Massachusetts 02543, USA
}

\begin{abstract}
Atlantic cod Gadus morhua is an extremely important fish in the northern hemisphere with respect to culture, economics, and ecology. However, the effects of over-fishing, environmental change, fish community dynamics and other factors that have altered the trophic ecology of cod are not well understood. We present an analysis of the trophic patterns of cod in the northeast US shelf ecosystem from a $25 \mathrm{yr}$ time series of food habits data. Additionally, we compared the diet of this species with the spatio-temporal distribution of its prey species and evaluated prey preference over time. Atlantic cod exhibit an omnivorous diet; we assessed the temporal, spatial, and ontogenetic trends in this diet by examination of $>15000$ stomachs. Ontogenetic shifts in diet were observed; early juveniles consumed more pelagic than benthic invertebrates, medium cod consumed benthic invertebrates and fish, and larger cod consumed larger amounts of fish. Cannibalism also increased with ontogeny. Diet shifted significantly over a period of 3 decades, concurrent with changes in forage species abundance and distribution. Most of the major prey species were eaten in periods when they had high spatio-temporal overlap with cod and were abundant, indicating opportunistic feeding by cod. Similar to many other ecosystems, cod prefer sand lance, Cancer spp. crabs and herring, regardless of the abundance or spatio-temporal overlap with these prey species. It is unclear whether the observed changes in the trophic dynamics of cod have broad implications for cod populations, yet the evidence does suggest that cod are not likely to influence the abundance and distribution of their prey populations in this ecosystem.
\end{abstract}

KEY WORDS: Feeding $\cdot$ Predator-prey interactions $\cdot$ Diet preference $\cdot$ Spatial overlap $\cdot$ Population dynamics $\cdot$ Northwest Atlantic $\cdot$ Atlantic $\operatorname{cod} \cdot$ Gadus morhua

Resale or republication not permitted without written consent of the publisher

\section{INTRODUCTION}

Atlantic cod Gadus morhua is arguably one of the most important fish on the planet. The historical, social and cultural importance of cod has been well documented (Jensen 1972, Kurlansky 1997). Even though the catch of this fish is a fraction of what it once was (e.g. Serchuk \& Wigley 1992, Garrod \& Schumaker 1994, Jakobsson et al. 1994, Serchuk et al. 1994, Murawski et al. 1997), it is still one of the top species in terms of global fisheries landings (Garcia \& Newton 1997, FAO 1998). This species remains a valuable fish

\footnotetext{
*E-mail: jason.link@noaa.gov
}

in continental shelf ecosystems in the north Atlantic, the Arctic and associated waters.

Atlantic cod is an important invertebrate and fish predator in numerous continental shelf ecosystems, and the diet of this species has been well chronicled (reviewed in Palsson 1994, Methven 1999). Cod are, or once were, the dominant piscivore in many ecosystems. Several models have estimated that the magnitude of cod predation on other fish and invertebrate populations can be significant, often as large as fisheries for the prey species (e.g. Andersen \& Ursin 1977, Helgason \& Gislason 1979, Daan \& Sissenwine 1991, Collie \& Tsou 1996, Bogstad et al. 1997, Overholtz et al. 2000, Link \& Garrison 2002). A large part of the energy in several ecosystems must pass through cod. 
As at the global level, cod in the northwest Atlantic no longer dominates fish community biomass, yet it remains a key component of regional fishery landings and is still an ecologically and culturally important species. The history of the US northwest Atlantic cod fishery and subsequent changes in the fish community are well documented (Serchuk \& Wigley 1992, Serchuk et al. 1994, Murawski et al. 1997, Fogarty \& Murawski 1998). This species supported an important fishery for centuries, before increasing exploitation in the 1950s and 1960s led to increased landings. Stock sizes declined in the 1970s and 1980s as landings increased. After these large increases in effort and landings, cod have persisted at low levels throughout the 1980s and 1990s and fish biomass is now dominated by elasmobranch and pelagic species. Although there has been some sign of recovery in other groundfish stocks, cod stocks have remained at low levels. The diet of cod in this part of the Atlantic has also been well documented at local scales and over short time periods (Langton \& Bowman 1980, Langton 1982, Bowman \& Michaels 1984, Vinogradov 1984). What is not known is how the impacts of overfishing, environmental change, fish community dynamics, and other factors have altered the trophic ecology of cod over larger spatial and temporal scales. Whether changes in trophic dynamics have any influence on cod or prey population dynamics is also not known.

Fisheries management and stock assessment science have usually taken a single stock approach to evaluating and predicting the population dynamics of exploited species. As fishing pressure is relaxed through management efforts to rebuild over-exploited stocks, it will be necessary to incorporate species interactions, particularly predator-prey interactions, into models in order to predict and manage stock recovery effectively (Jennings \& Kaiser 1998, EPAP 1999). Toward this goal, we present an analysis of the trophic patterns of cod in the northeast US shelf ecosystem from a $25 \mathrm{yr}$ time series of food habits. We assess the temporal, spatial, and ontogenetic trends in cod diet. Additionally, we compare the diet of this species with the spatio-temporal distribution of its prey in the ecosystem and evaluate prey preference over time. Our primary objective was to ascertain the major determinants of cod diet and how the diet reflected changes in the prey field.

\section{MATERIALS AND METHODS}

Data collection. The data for this study were collected from seasonal bottom trawl surveys conducted by the Northeast Fisheries Science Center (NEFSC). The surveys employ a stratified random sampling design with strata defined by depth and latitude. Sample depths ranged between 8 and $400 \mathrm{~m}$. Stations were defined by $2.5^{\prime}$ latitude by 2 ' longitude rectangular units that were randomly selected within strata. Between 350 and 400 stations on the continental shelf between Cape Hatteras, North Carolina and southwestern Nova Scotia (Fig. 1) were sampled during each seasonal survey of ca. 4 to $6 \mathrm{wk}$ in duration (NEFC 1988). At each station, a 36 Yankee (or similar) bottom trawl was deployed for $30 \mathrm{~min}$ and towed at a speed of $6.5 \mathrm{~km} \mathrm{~h}^{-1}$. Sub-standard tows or those with non-representative sampling due to gear damage were removed prior to analyses. Although winter and summer surveys have been executed intermittently throughout the time series, the majority of the data comes from the spring and autumn surveys. For each tow, catch (in both mass and numbers) at length (1 cm length classes) was recorded for all species. Details of the survey sampling design, execution, and

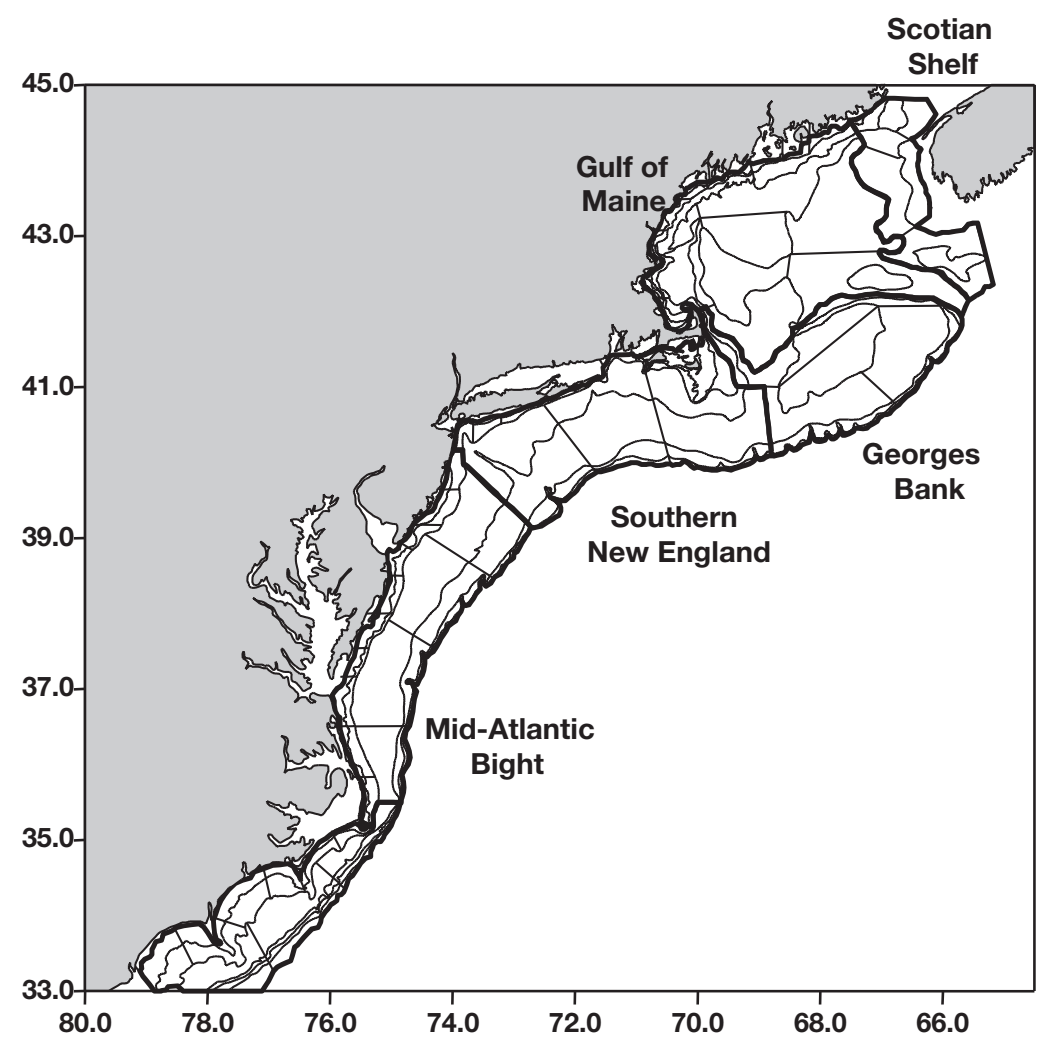

Fig. 1. The northeast US continental shelf. Thick lines indicate subarea designations and thin lines demarcate the sampling strata used in NEFSC resource bottom trawl surveys 
efficiency are available in Azarovitz (1981) and NEFC (1988).

In addition to catch data, a subset of species was analyzed for age and food habits data during each seasonal cruise. The NEFSC has conducted quantitative food habits sampling in seasonal surveys from 1973 to the present. Prior to 1981, stomach contents were preserved and returned to the laboratory for identification of prey items. Total stomach content mass and the mass of each prey was measured to the nearest $0.1 \mathrm{~g}$. Since 1981, stomach contents have been examined at sea. The total volume of stomach contents was measured and the proportion of stomach contents comprised by each prey item was estimated.

At points during the time series, prey amounts were measured as both weights and volumes within the same stomachs for a wide variety of species. Using these samples, a linear regression was performed to convert volumes to weights and resolve the differences in prey quantification during the 2 periods. The regression was highly significant $\left(r^{2}>0.90, p<0.0001\right)$ and prey volumes from the 1981 to 1998 time period were multiplied by 1.1 in order to convert volumes to weights based upon this analysis (Link \& Almeida 2000). Further details of the food habits sampling methodology are available in Link \& Almeida (2000). The current study encompassed data collected from Cape Hatteras, NC, to southwestern Nova Scotia between 1973 and 1998 during all seasons.

Prey and predator categories. Since stomach contents were identified in the laboratory prior to 1981, the taxonomic resolution of invertebrate prey is generally higher in these samples. In the current study, invertebrate prey were grouped into families or orders in order to account for differences in taxonomic resolution between the sampling periods. Fish prey were generally identified to species when possible. Unidentifiable fish were an important component of the diets of the cod in this study, including both well-digested remains and small fish that were difficult to identify in both preserved and fresh samples. While it is assumed that unidentifiable fish and well-digested animal remains reflect the composition of identifiable prey in the diet, we have chosen to be conservative by including them as separate prey types in our analyses.

We executed a cluster analysis and identified 3 major length categories of cod that exhibit consistent diet compositions when pooled across the time series in $10 \mathrm{~cm}$ size categories (Fig. 2): $<10 \mathrm{~cm}$ (small), 10 to $50 \mathrm{~cm}$ (medium), and $>50 \mathrm{~cm}$ (large). Cod were then grouped into these 3 length categories to account for known ontogenetic shifts

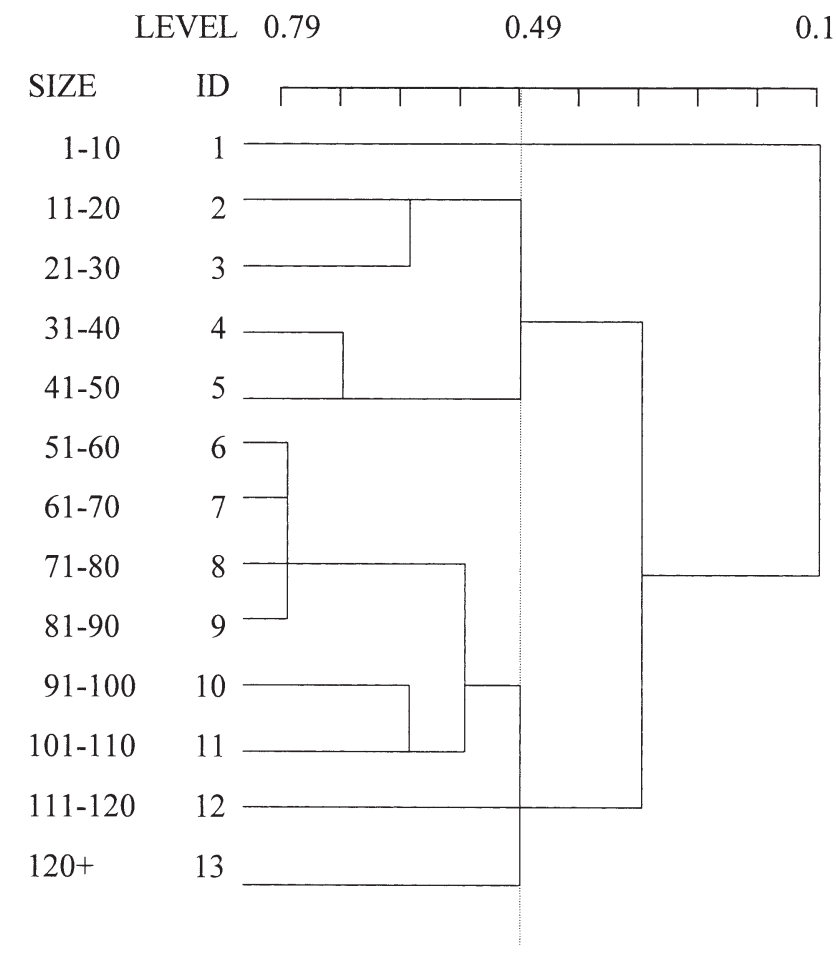

Fig. 2. Gadus morhua. Cluster diagram of diet similarity for cod grouped in $10 \mathrm{~cm}$ size classes

in diet (Durbin et al. 1983, Bowman \& Michaels 1984, Garrison \& Link 2000a). Summary statistics for all size classes are shown in Table 1.

Diet analyses. Means and variance of prey amount (weight) per stomach were calculated using a weighted, 2-stage cluster design to account for survey sampling design and included empty stomachs (Link \& Almeida 2000). Mean stomach contents within a tow were weighted by the number of cod in a size category captured in that tow. We assessed general trends in means and $95 \%$ confidence intervals of relative prey amounts (\% of diet by weight) by cod size category (small, medium, and large), geographic region (Fig. 1), season (corresponding to winter, spring, summer, and autumn surveys), and time blocks (1973-1975, 1976-1980, 1981-1985, 1986-1990, 1991-1995,

Table 1. Gadus morhua. Summary of cod examined in this study. Mean weights (wt) in $\mathrm{g}$

\begin{tabular}{|lcrcccc|}
\hline Size & $\begin{array}{c}\text { Length } \\
\text { range }(\mathrm{cm})\end{array}$ & $\begin{array}{c}\text { No. } \\
\text { examined }\end{array}$ & $\begin{array}{c}\text { Mean stomach } \\
\text { wt (SE) }\end{array}$ & $\begin{array}{c}\text { Mean fish } \\
\text { wt }\end{array}$ & $\begin{array}{c}\text { No. of } \\
\text { tows }\end{array}$ & $\begin{array}{c}\text { No. empty } \\
(\%)\end{array}$ \\
\hline Small & $<10$ & 156 & $0.086(0.064)$ & 4.5 & 13 & $18(11.5 \%)$ \\
Medium & $10-50$ & 6815 & $7.37(0.188)$ & 581.3 & 573 & $957(14.0 \%)$ \\
Large & $>50$ & 8176 & $68.86(1.25)$ & 3405.9 & 2461 & $1320(16.1 \%)$ \\
\hline
\end{tabular}


1996-1998) for cod. The time block (usually 5 yr) provided sufficient resolution of temporal trends while maintaining adequate sample size.

A canonical correspondence analysis $\left(\mathrm{CCA}_{\text {; }}\right.$ ter Braak 1986) assessed the multivariate diet response to the 4 explanatory factors above. The explanatory factors were coded to ordinal variables reflecting size (small, medium, or large), geographic (southern to northern), seasonal (winter to autumn), and temporal (1973-1998, in time blocks) groups. The response matrix consisted of the mean amount of each prey category within each cell of the crossed factors and were $\log$ transformed $(\ln [x+1])$ to account for the log-normal distribution of prey weights. Tows containing less than 5 fish and cells containing less than 5 tows were removed from the analysis to avoid inflation of variance due to low sample sizes.

CCA is a multivariate equivalent to a multiple, nonlinear regression (ter Braak 1986, 1987). It is a direct gradient method whereby canonical axes that are linear combinations of explanatory variables are correlated to weighted averages of multivariate response variables (prey amounts) within cells. The statistical significance of explanatory factors in the ordination was assessed using permutation tests (ter Braak 1986). The results of the CCA are expressed in prey-environment biplots, by examining the correlation between the canonical axes and explanatory variables, and by examining the amount of variation in the prey matrix explained by the canonical axes (ter Braak 1986, 1987). CCA is an effective method to statistically assess the quantitative relationship between multivariate response and explanatory variables, and it is extremely robust to violations of assumptions (e.g. non-normality, ter Braak 1986, Palmer 1993). The CCA ordination was accomplished using CANOCO Version 4.0.

Species distribution. A mean number per tow was calculated within $0.5^{\circ}$ squared grid cells in order to evaluate the spatial distribution of cod and its major prey species. This was done for cod (sizes combined) and major prey species. These means incorporated all seasons that were surveyed in a given time block. We also calculated the Williamson (1993) overlap index to assess spatial overlap between cod and its major prey. We did this for each time block using the mean number per tow in each $0.5^{\circ}$ squared grid cells. Values of the index range from 0 to the number of sampling locations (i.e. the number of grids, ca. 145). If the index is 1 , the degree of overlap is not different from the expectation where the species are uniformly distributed. A value $<1$ indicates less than expected overlap while a value $>1$ indicates greater than expected overlap.

No statistical test exists to evaluate the deviation of the observed overlap from the random expectation when species are uniformly distributed. To examine the significance of the Williamson overlap index, we executed a randomization test appropriate for correlation coefficients with a similar form (Manly 1997). We tested the observed value for each species pair against a null hypothesis of no spatial relationship generated from a random distribution of overlap values. For each species pair we randomly (with replacement) selected values from species $j$ (i.e. cod) to pair with the abundance of prey species $i$ at each site and calculated the randomized Williamson index. The randomization was executed 4999 times, with the observed value being the 5000th instance. The probability of no spatial relationship was the proportion of randomized observations with deviations from 1 greater than or equal to the observed value.

Preference. To ascertain the level of feeding preference exhibited by cod, we calculated the percentage frequency of occurrence in the diet and in the tows for major cod prey. This ordinal index differs from classical methods of assessing selectivity in that we used frequency of occurrence rather than absolute or relative abundance data (e.g. Strauss 1979, Manly et al. 1993). We used an occurrence approach because of the difficulty in assessing the catchability, and hence abundance, of certain prey species with the bottom trawls (Clark \& Brown 1977, NEFC 1988). The occurrence data is ordinal and is thus less susceptible to these considerations. We ranked the percentage frequency in both cod stomachs and the tows for 8 major prey items. The difference between these ranks is an index of preference, ranging from 8 to -8 . High positive values indicate preference, high negative values indicate avoidance, and values near 0 indicate no preference. We estimated preference for both medium and large cod, but not for small cod due to the limited sample size.

\section{RESULTS}

\section{Cod diet}

Over 15000 Atlantic cod stomachs were examined in this study (Table 1). The vast majority of these fish were larger than $10 \mathrm{~cm}$. Overall, ca. $15 \%$ of the stomachs examined were empty. There were at least 200 and often $>1000$ tows where cod was collected across all levels of the time blocks, seasons or regions, except for the Mid Atlantic Bight with only 27 tows.

The diet of small cod consisted primarily of mysids (Fig. 3A). Other prey items were principally shrimps and other crustaceans. Medium cod similarly ate crustaceans such as pandalids, amphipods and shrimp (Fig. 3B). However, cod $>30 \mathrm{~cm}$ consumed more crabs and fish (silver hake, sand lance) than smaller size classes. Well-digested prey was a notable amount of 

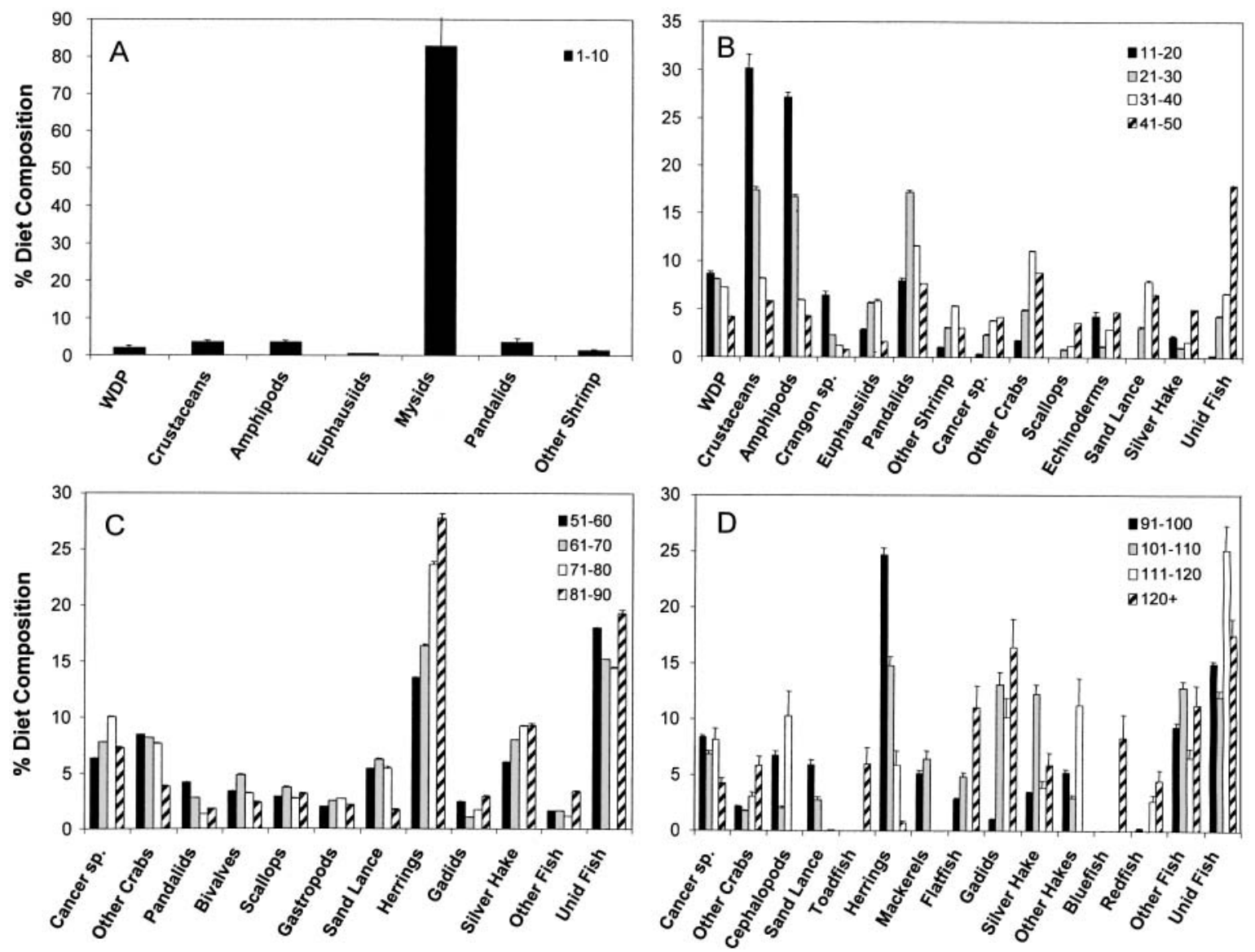

Fig. 3. Gadus morhua. Diet of cod across different size classes. Mean \% weight of diet for major prey by $10 \mathrm{~cm}$ size classes. Error bars represent $95 \%$ confidence intervals. Sample sizes for the different size classes (starting with 1-10, then 11-20 etc.) are 156, $452,1335,2194,2834,2799,2326,1525,856,391,161,75$ and 43 respectively. WDP = 'well-digested prey'

the diet, as were echinoderms and scallops. Large cod were significantly more piscivorous than smaller sizes (Fig. 3C,D). Herring, silver hake, other gadoids and unidentified fish were the major components of the diet of larger cod. Additionally, larger cod ate more molluscs than smaller sizes, yet crabs were still an important part of the diet. Cod $>120 \mathrm{~cm}$ also ate toadfish, bluefish, and redfish (Fig. 3D). The importance of crustaceans and shrimp diminished in the diet of large cod, but large cod still exhibited a very catholic diet. With the exception of the smallest size class, it took at least 12 prey types to adequately characterize the major diet components of cod.

Although the diet of cod was broad, there were notable regional differences observed in the diet. For example, only small amounts of crabs or sand lance occurred in the diet in the northern areas (Fig. 4A), whereas these were major components of the diet in southern areas (Fig. 4B). Similarly, silver hake and mackerel were uncommon in southern areas but were a large component of the diet in the northern areas.
Redfish was consumed almost exclusively in the Gulf of Maine and Scotian Shelf areas. Scallops, squids, and gastropods were consumed primarily on Georges Bank. There was a general trend of more invertebrate prey in the southern regions and more fish prey in the northern areas, yet the diet of cod was still very broad in all areas.

Regardless of season, cod diet consisted primarily of herrings, unidentified fish, squids, silver hake, shrimps, and crabs (Fig. 5). However, there were less herring in the spring, more squid in the summer and fall, and more silver hake in the fall than other seasons.

Across the time series there were significant changes in cod diet (Fig. 6). Ocean pout, flatfish, redfish, other gadoids, mackerels and herring were most important in the diet of cod in the 1970s (Fig. 6A). The importance of these species in the diet declined in the 1980s. Only herring re-emerged as a major component of cod diet, becoming the major prey item during the 1990s (Fig. 6B). Squid were a notable component of the diet only during the late 1970 s. Similarly, sand lance com- 


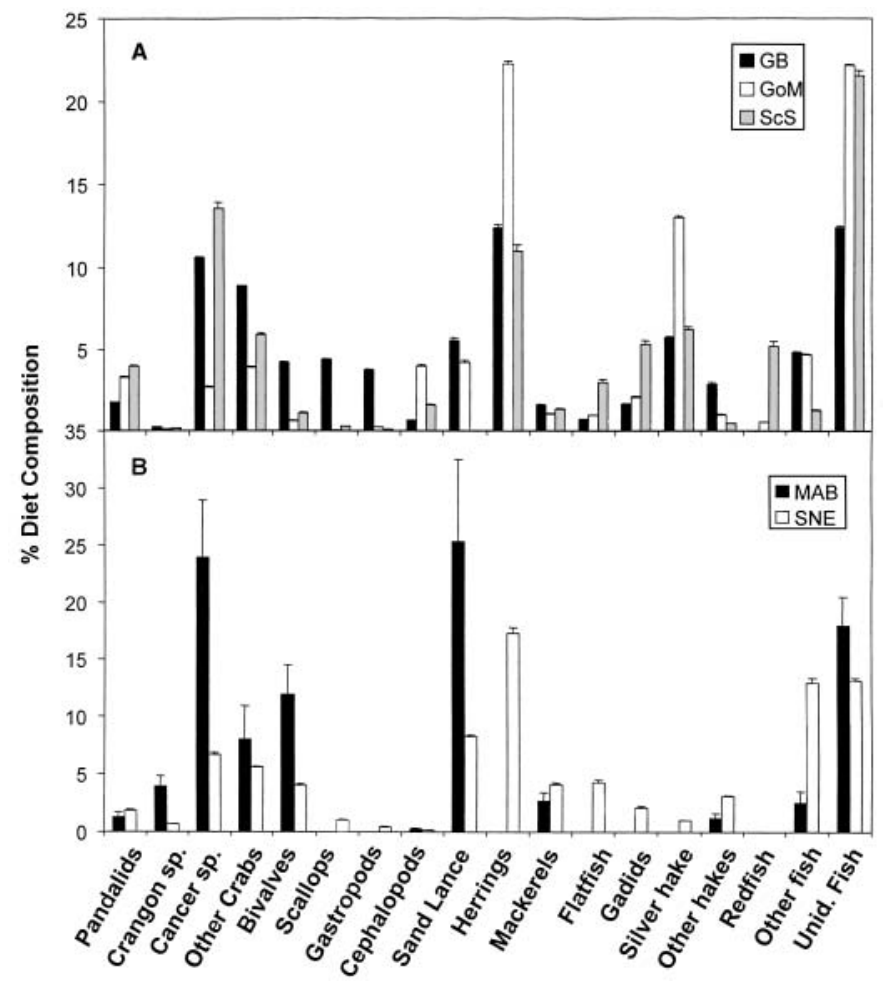

Fig. 4. Gadus morhua. Diet of cod across geographic region. $\mathrm{GB}=$ Georges Bank $(\mathrm{N}=6111), \mathrm{GoM}=$ Gulf of Maine $(\mathrm{N}=$ 5892), $\mathrm{ScS}=$ Scotian Shelf $(\mathrm{N}=2051), \mathrm{MAB}=$ Mid-Atlantic Bight $(\mathrm{N}=36), \mathrm{SNE}=$ Southern New England $(\mathrm{N}=1057)$

prised a major portion of the diet only in the late 1970s and early 1980s. Silver hake and other hakes were most important in the diet in the late 1980s and early 1990s. Other fish (species such as sculpins, lizardfish, cunner, wolffish, snailfish, alligatorfish, snake blennies, shannies, gunnels, eels, argentines, wrymouth) were more important in cod diet during the late 1970s and 1980s. Only crabs and unidentified fish showed no significant change as components of cod diet across the time series.

The CCA ordination for cod accounted for $10.0 \%$ of the total variation in the diet data. Of this, $87.2 \%$ was accounted for by the first 2 CCA axes. The first axis was negatively correlated with size class $(\mathrm{r}=-0.973$, $\mathrm{p}<0.001$ ), while the second was related to time block $(r=-0.835, p<0.001$; Fig. 7). Axis 1 delineates a gradient from fish to invertebrate prey. Fish and cephalopod prey have a higher negative score, corresponding to significantly greater amounts of these prey in larger cod (Figs. 3 \& 7). Conversely, shrimps, mysids, euphasiids, and amphipods have a positive Axis 1 score, corresponding to their significantly greater importance in the diet of smaller cod. In more recent years (negative Axis 2 scores), herrings, bivalves and Crangon sp. have been significantly more important

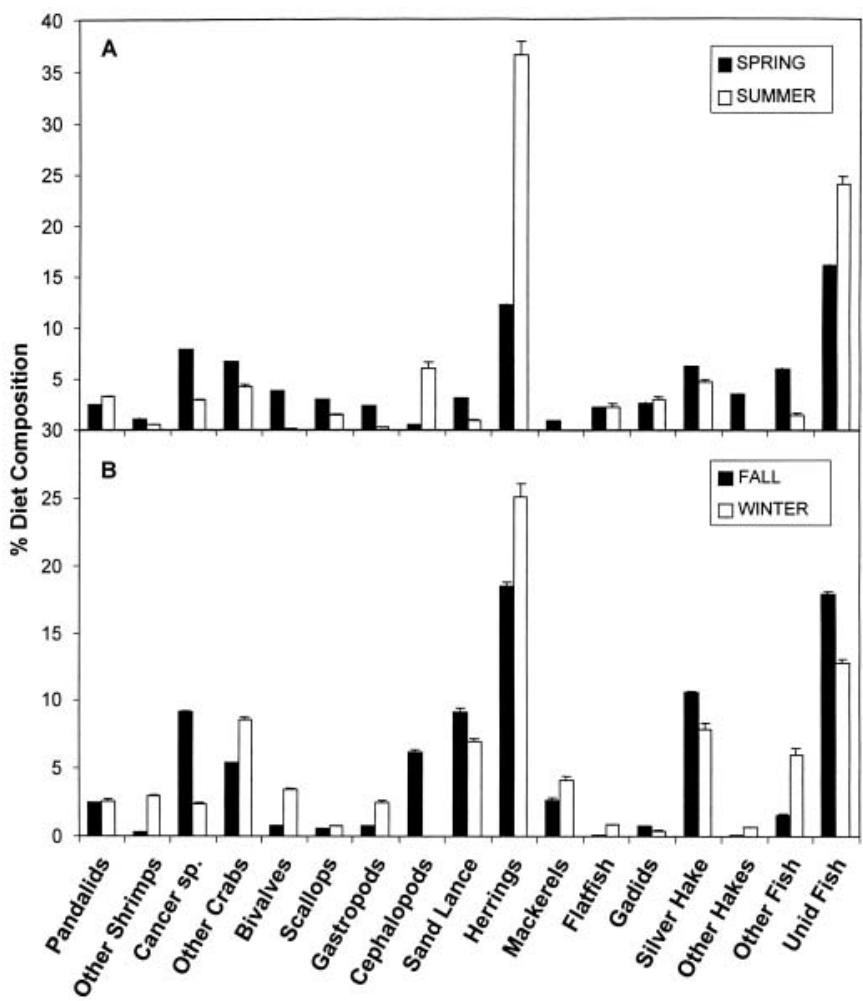

Fig. 5. Gadus morhua. Diet of cod across seasons. Sample sizes for spring, summer, fall and winter are 7957, 946, 5116, and 1128 respectively

in the diet of cod, whereas squids, echinoderms, flatfish and worms were more important in the diet of cod earlier in the study (Figs. 6 \& 7). The consistent amount of crabs in the diet of cod across all factors of this study explains why this prey item was at the center of the CCA biplot (Fig. 7).

\section{Species distribution}

The majority of cod occurred in the Gulf of Maine, Georges Bank and the Scotian Shelf regions (Fig. 8). Cod abundance declined across the time series, with much lower values observed in the 1990s than the 1970s. Cod were much less abundant in southern regions in the 1990s than during the 1970s, implying an effective contraction of the distribution of cod over the past 3 decades.

Illex spp. were widespread and most abundant along the continental shelf slope, particularly on southern Georges Bank, offshore Southern New England, and the Mid-Atlantic Bight (Fig. 9). Illex spp. were most abundant during the later 1970s and were much more abundant in the Gulf of Maine and northern Georges Bank, where the majority of cod were located during 


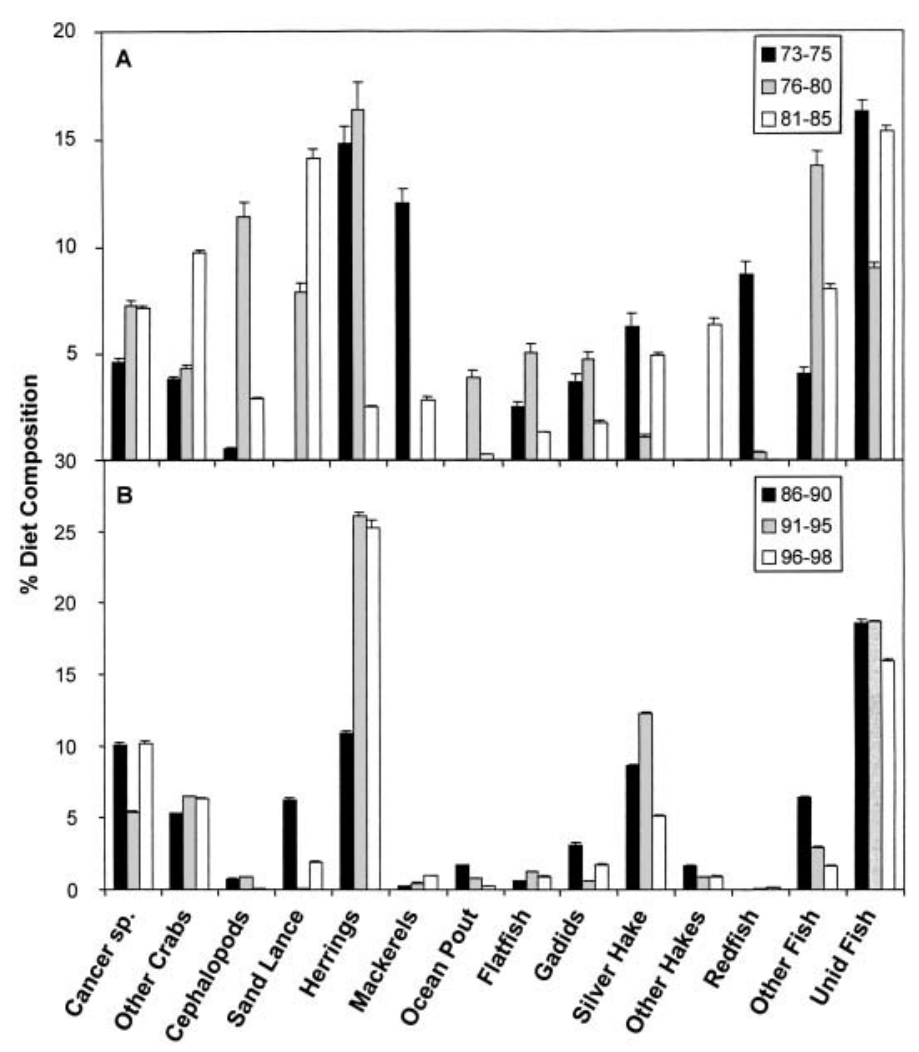

Fig. 6. Gadus morhua. Diet of cod across time blocks. Sample sizes for the time blocks $(1973-1975,1976-1980$ etc.) are 1040, 1001, 2564, 4602, 4043, and 1897 respectively
Sand lance occurred in the Mid Atlantic Bight, Southern New England, and Georges Bank areas (Fig. 12). This species was clearly most abundant in the late 1970s and 1980s. The distribution expanded and contracted coincident with the abundance of this species. Both these time periods (Fig. 6A) and regions (Fig. 4B) corresponded to the greatest contribution of sand lance to the diet of cod.

The distribution of Atlantic herring expanded across the time series, with an increasing presence in more southern regions (Fig. 13). This corresponded to the notable increase in herring abundance observed in the 1990s. Cod and herring co-occurred more in the 1970s than in the 1980s (Fig. 8), corresponding to the high amounts of herring in the diet of cod during that time (Figs. 3 \& 6A). In the 1990s herring was again the dominant component of cod diet (Fig. 6B), concurrent with the high abundance of this prey species.

The spatial overlap index showed that cod had consistently and significantly low spatial overlap values with Loligo spp. squid, spotted hake, and Cancer spp. (Table 2). The former 2 prey items are distributed near the continental shelf break, whereas the Cancer spp. crabs are more southern in distribution (Fig. 11). Similarly, mackerel did not co-occur very often with cod. White hake, this time period (Fig. 8). This time period was also concurrent with the highest incidence of squid in the diet of cod (Fig. 6A).

Redfish were distributed primarily in the Gulf of Maine across this time series (Fig. 10). The highest cooccurrence of redfish and cod occurred in the Gulf of Maine in the 1970s and 1990s, concurrent with the highest incidence of redfish in the diet of large cod (Figs. 3D \& 6A).

Cancer spp. (C. irroratus, C. borealis, and undetermined species) crabs were widespread throughout the sampling area, but were slightly more abundant in southern regions (Fig. 11). This distribution corresponded to the slightly higher amount of crabs in the diet of cod in those regions (Fig. 4b). These crabs were more abundant in the 1970 s to 1980 s, but were more widespread in the 1990s.

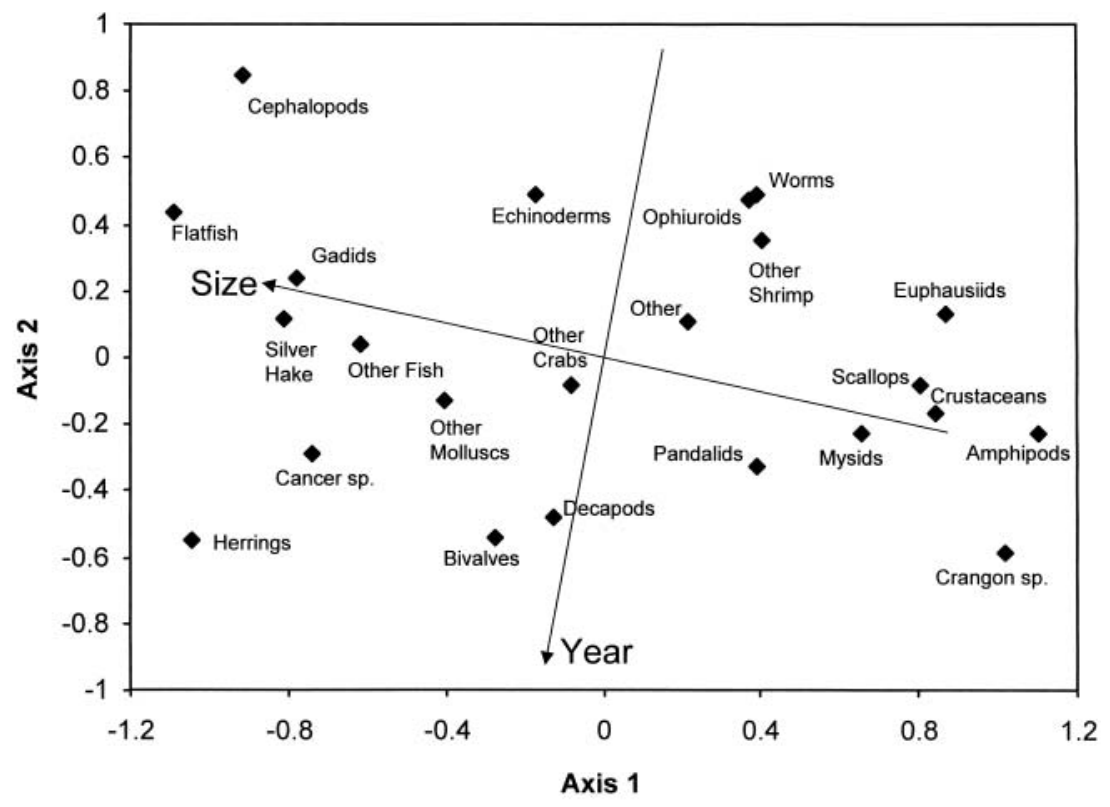

Fig. 7. Gadus morhua. CCA biplot for cod diet. Arrows indicate significant predictors, with the arrowhead indicating positive values of the variable. A small angle between a variable arrow and a CCA axis indicates high correlation between the axis and the variable. Points indicate scores of individual prey types in the ordination space 

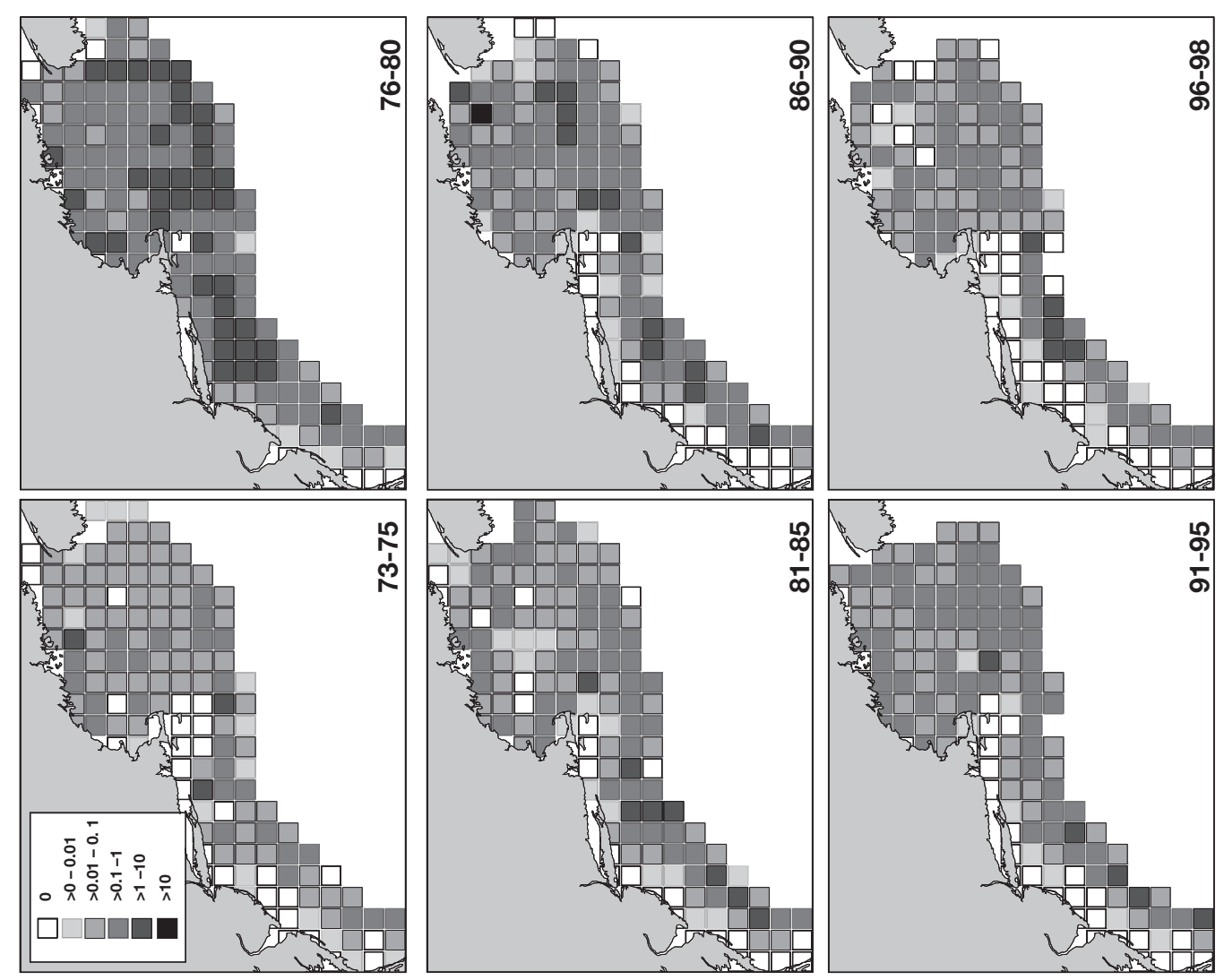

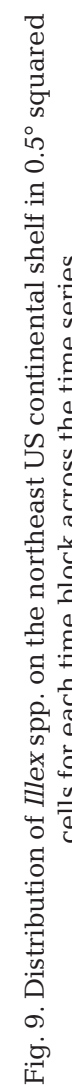
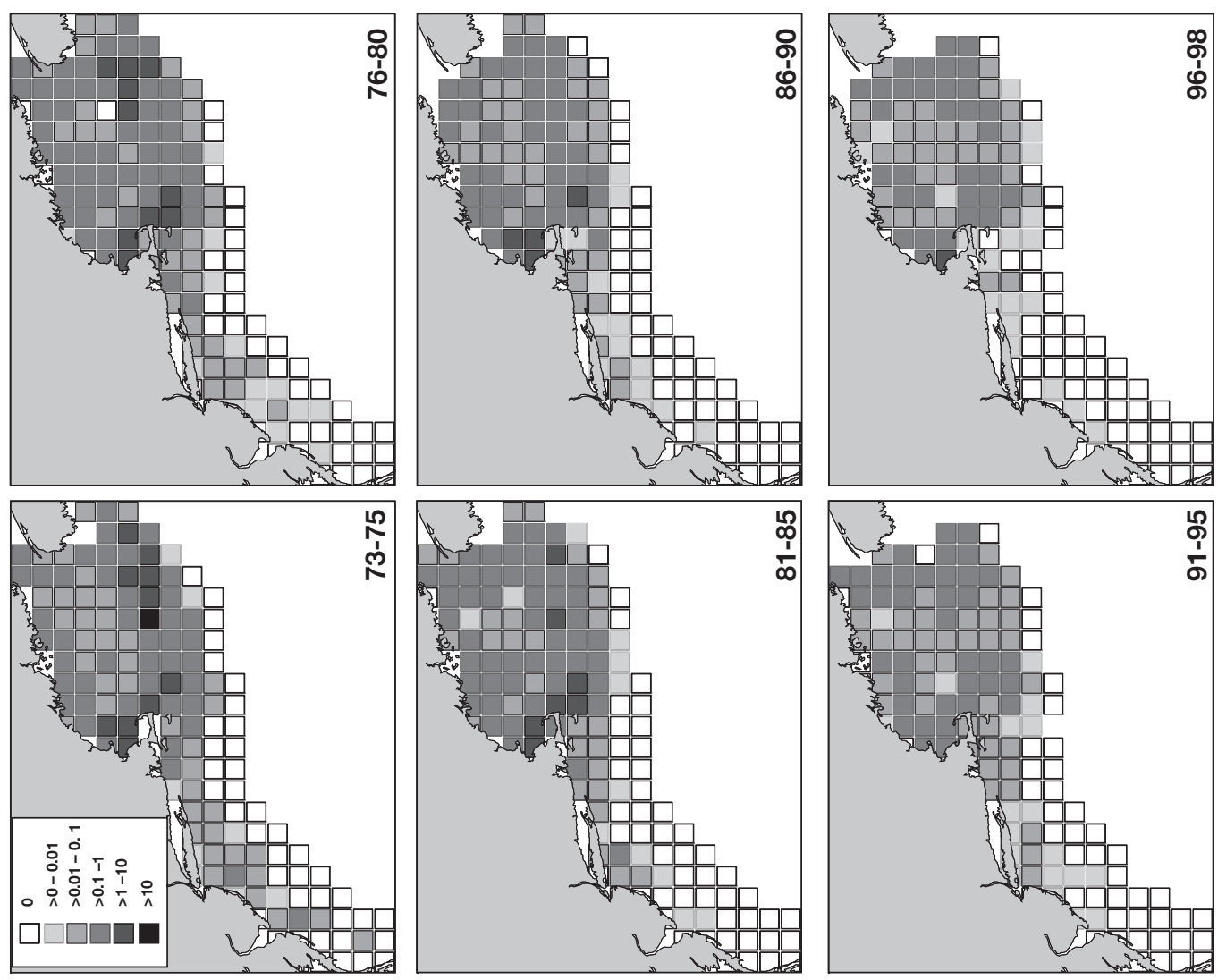

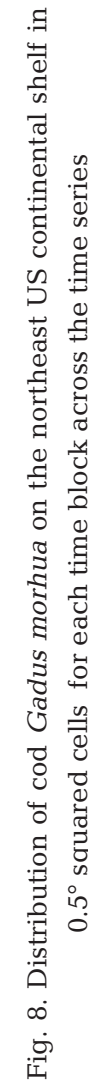



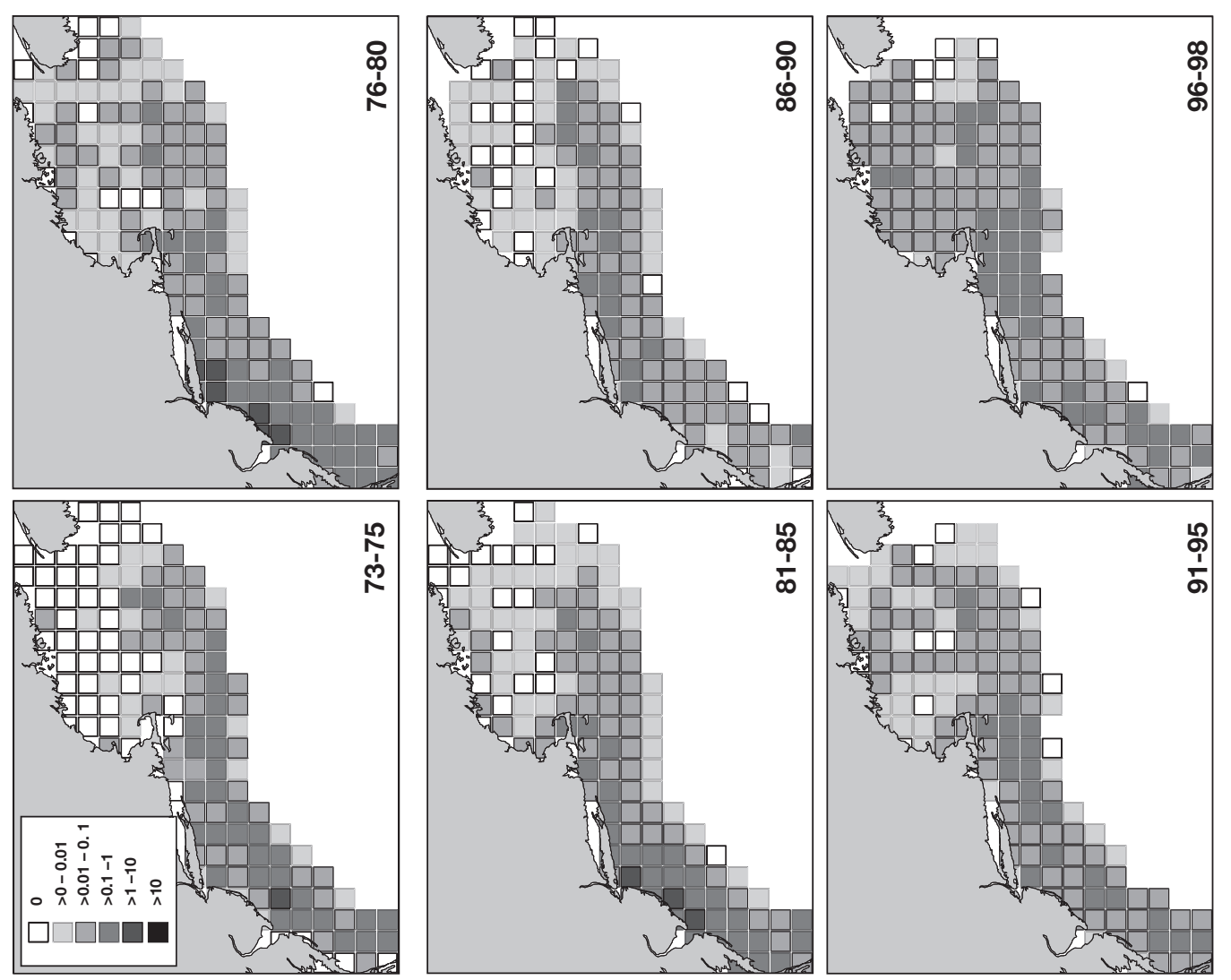

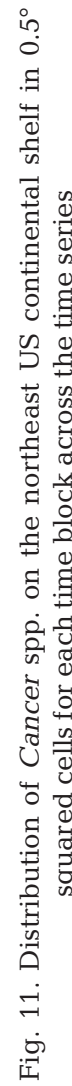
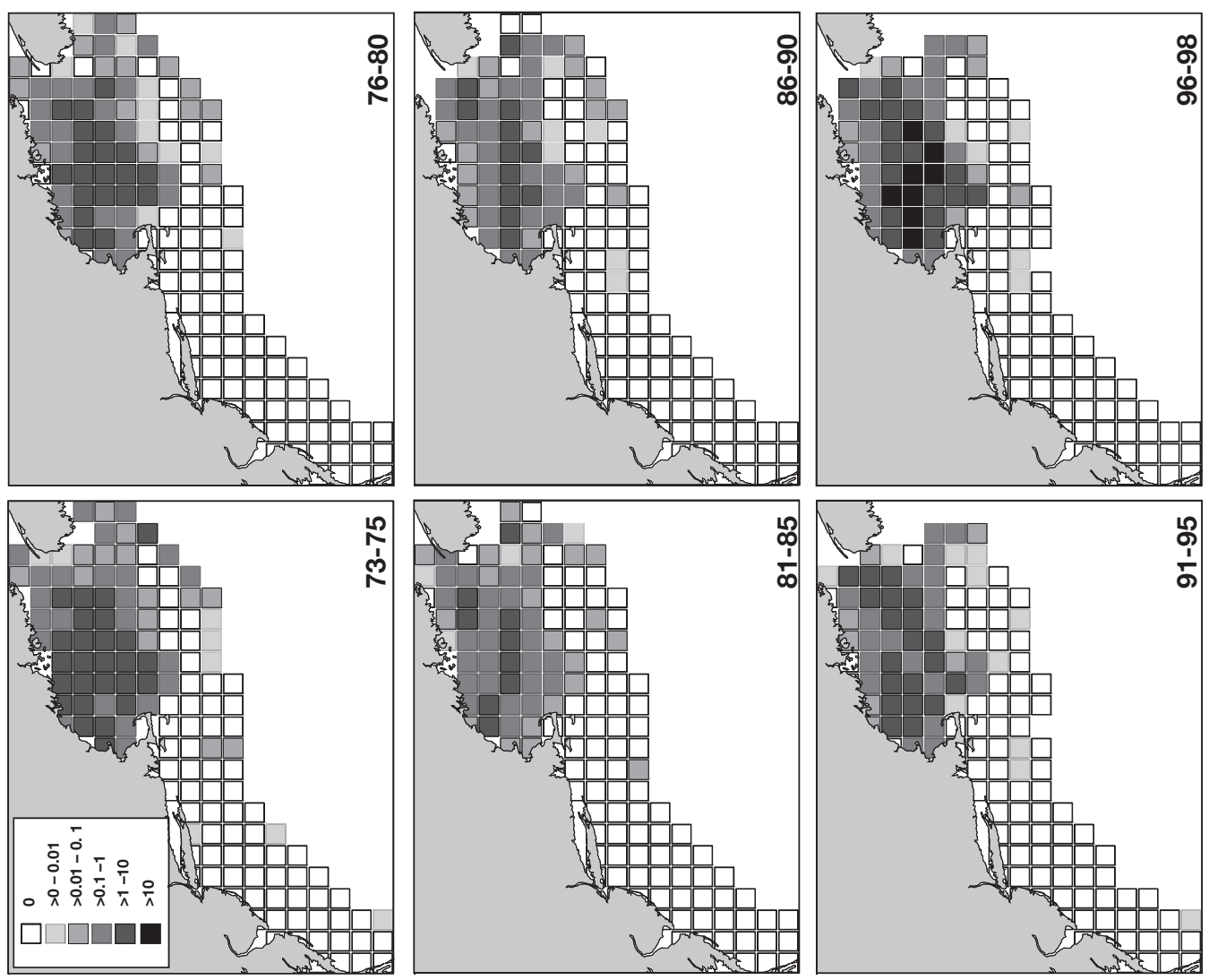

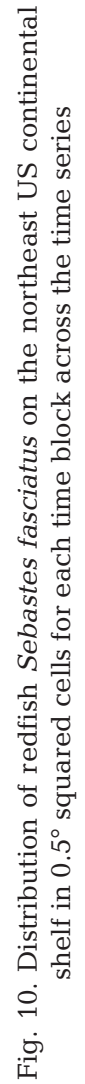



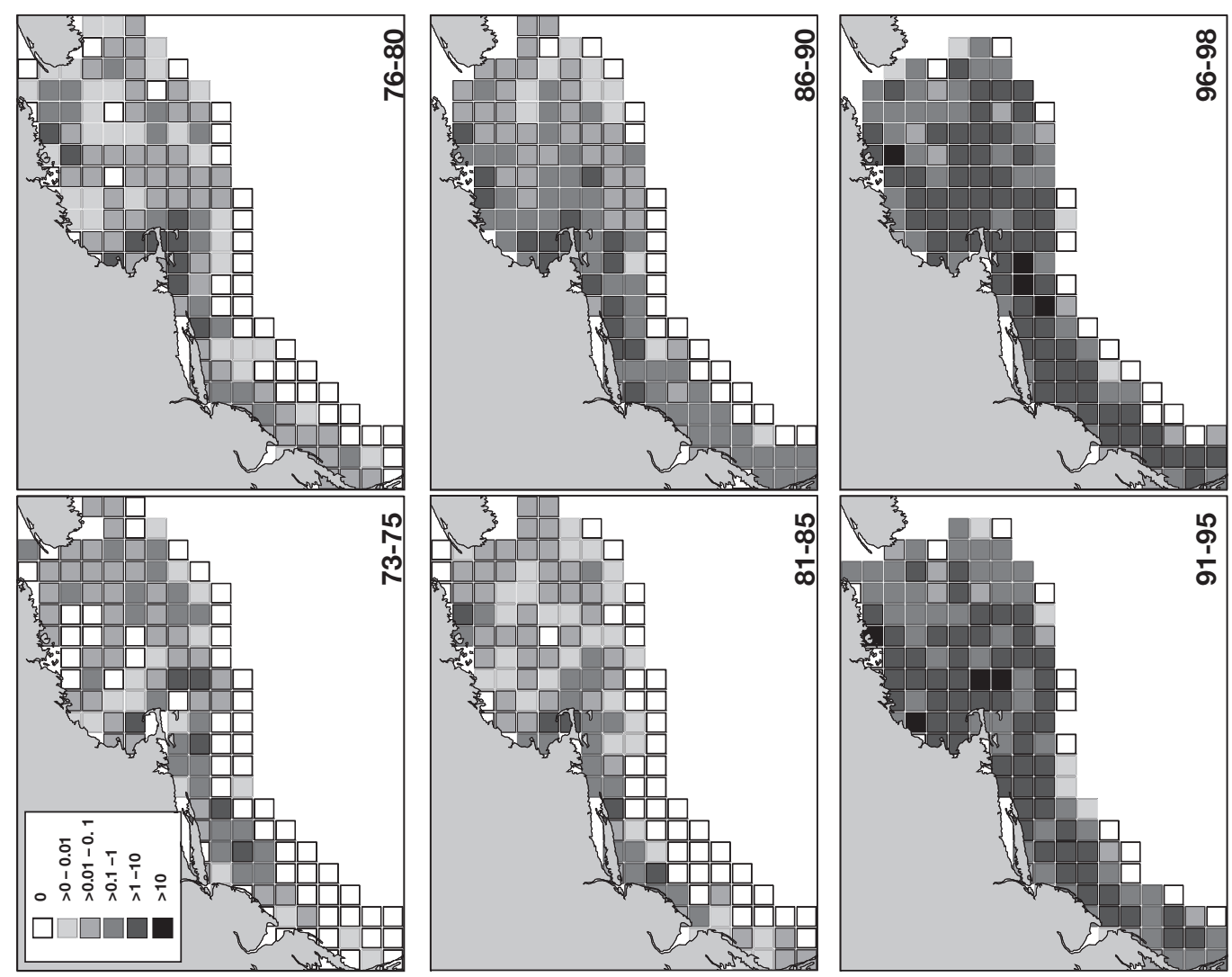

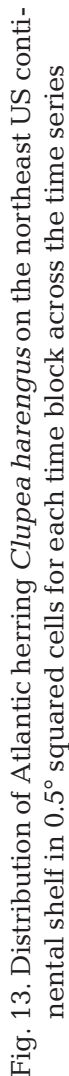
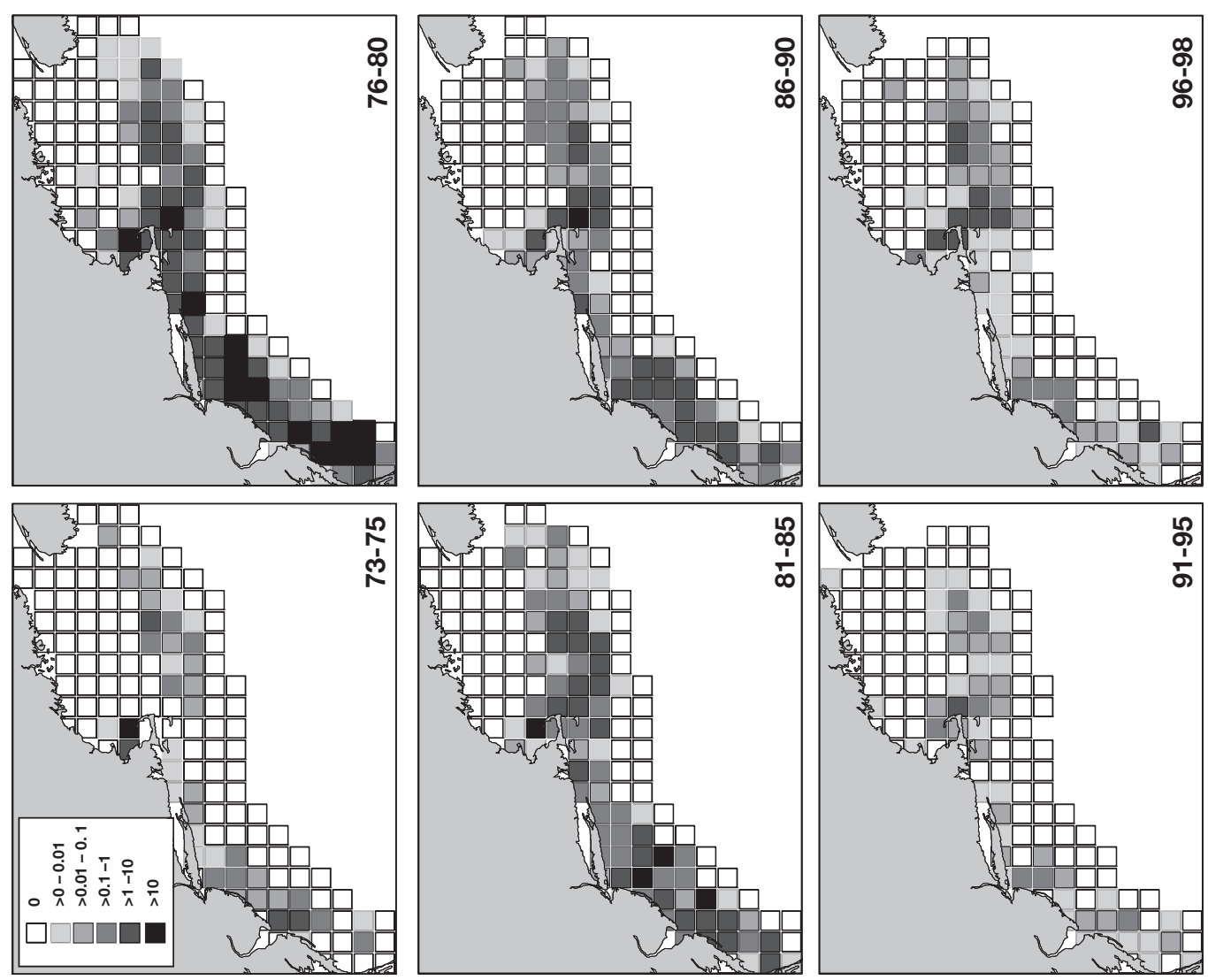

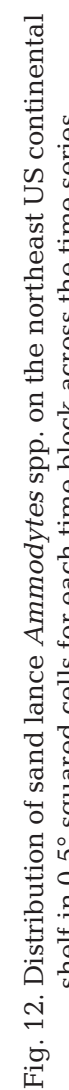


Table 2. Williamson spatial overlap values for major prey items and cod across the time series. A value $<1$ indicates less than expected overlap, a value $>1$ indicates greater than expected overlap, and a value $=1$ indicates the species are uniformly distributed. ${ }^{\mathrm{a}} \mathrm{p} \leq 0.05,{ }^{\mathrm{b}} \mathrm{p} \leq 0.01,{ }^{\mathrm{c}} \mathrm{p} \leq 0.005,{ }^{\mathrm{d}} \mathrm{p} \leq 0.001$

\begin{tabular}{|lcccccc|}
\hline & $1973-1975$ & $1976-1980$ & $1981-1985$ & $1986-1990$ & $1991-1995$ & $1996-1998$ \\
\hline Atlantic mackerel & 0.225 & 0.502 & 0.571 & $0.130^{\mathrm{d}}$ & $0.171^{\mathrm{d}}$ & $0.442^{\mathrm{a}}$ \\
Redfish & 0.700 & 1.384 & 1.187 & $2.116^{\mathrm{a}}$ & $2.200^{\mathrm{b}}$ & $2.255^{\mathrm{a}}$ \\
Sand lance & $8.414^{\mathrm{c}}$ & 1.078 & $3.023^{\mathrm{b}}$ & $2.136^{\mathrm{a}}$ & 1.794 & $2.449^{\mathrm{a}}$ \\
Ocean pout & 1.235 & 0.922 & $1.893^{\mathrm{a}}$ & $1.674^{\mathrm{a}}$ & 0.977 & 0.816 \\
Cancer spp. & 0.605 & $0.200^{\mathrm{d}}$ & $0.240^{\mathrm{d}}$ & $0.857^{\mathrm{d}}$ & $0.462^{\mathrm{a}}$ & 0.568 \\
Atlantic herring & 1.885 & $1.774^{\mathrm{c}}$ & $2.054^{\mathrm{a}}$ & $2.347^{\mathrm{c}}$ & $1.720^{\mathrm{a}}$ & 0.849 \\
Sea scallops & 0.513 & 0.900 & 1.361 & $0.289^{\mathrm{a}}$ & 0.535 & 0.594 \\
Illex spp. & 0.496 & $1.457^{\mathrm{a}}$ & 1.249 & 1.418 & 0.927 & 0.705 \\
Loligo spp. & $0.255^{\mathrm{d}}$ & $0.257^{\mathrm{d}}$ & $0.369^{\mathrm{d}}$ & $0.225^{\mathrm{d}}$ & $0.292^{\mathrm{d}}$ & 1.021 \\
Silver hake & 1.221 & 0.807 & 1.111 & 1.211 & $1.770^{\mathrm{a}}$ & 1.022 \\
White hake & 1.218 & $1.550^{\mathrm{a}}$ & 1.349 & 1.392 & 1.138 & $1.721^{\mathrm{a}}$ \\
Red hake & 1.065 & 1.053 & 1.141 & $1.555^{\mathrm{a}}$ & $0.013^{\mathrm{d}}$ & $0.002^{\mathrm{d}}$ \\
Spotted hake & $0.040^{\mathrm{d}}$ & $0.009^{\mathrm{d}}$ & $0.006^{\mathrm{d}}$ & $0.004^{\mathrm{d}}$ & & \\
\hline
\end{tabular}

red hake, herring, and sand lance generally exhibited high spatial overlap values with cod. The overlap declined for hakes (gadoids) and herring in the later 1990s, yet all were notable components of the diet across time and the geographic regions (Figs. 4 \& 6). The highest overlap values of sand lance with cod generally coincided with periods when sand lance was a larger component of cod diet (Fig. 6). Scallops, Illex spp., and silver hake were uniformly distributed with respect to cod distribution.

\section{Preference}

Both large and medium cod exhibited a strong preference for herring, Cancer spp. and sand lance across the time series (Fig. 14). Conversely, silver hake and other hakes had large negative preference values across the time series. Several prey organisms exhibited neutral preference by large cod, including redfish, mackerel, and squid. Medium cod similarly had neutral values for redfish and squid. Both large and medium cod showed a small decline in preference for mackerel across the time series, while alternating (albeit at low magnitudes, usually between \pm 2 ) among preference, no preference, and avoidance for squid and redfish, generally implying neutral preference for these prey species.

The preference for herring and sand lance corresponds to the high co-occurrence of these species with cod during periods when these prey species were very abundant (Figs. 12 \& 13). The preference for Cancer spp. crabs may be related to their widespread distribution across time (Fig. 11), but the avoidance of silver hake, which is also widespread, is noteworthy.

\section{DISCUSSION}

Atlantic cod clearly exhibits an omnivorous diet that is similar to that found in many other studies (e.g. Langton \& Bowman 1980, Langton 1982, Bowman \& Michaels 1984, Vinogradov 1984, Mattson 1990, Grunwald \& Koester 1994, Palsson 1994, Hoines \& Bergstad 1999). The generalist feeding nature encompasses the spectrum from invertebrate to fish and from benthic to pelagic prey. Cod has one of the broader feeding habits among fish.

Atlantic cod exhibits clear ontogenetic shifts in diet. A shift in diet occurred among juvenile cod, with a switch from mysids and similar pelagic invertebrates to benthic invertebrate prey (Fig. 3). These shifts in juvenile cod feeding are similar to those described in other studies (Bowman 1981, Huessy et al. 1997, Grant \& Brown 1998, Lomond et al. 1998). This diet shift occurs during the critical life period of juvenile settlement and can influence juvenile survival and recruitment success, particularly if there is insufficient benthic prey available (Huessy et al. 1997). Additionally, piscivory increases as cod become larger. Fish become a much larger component of the diet in $\operatorname{cod}>50 \mathrm{~cm}$, a finding which is consistent with the results of other studies (e.g. Durbin et al. 1983, Bowman \& Michaels 1984, Konstantinov et al. 1985, Casas \& Paz 1994, Palsson 1994). Additionally, cannibalism is observed most frequently in cod $>100 \mathrm{~cm}$ (cf. gadoids, Fig. 3D). How these cannibalistic effects influence stock dynamics is unclear (Smith \& Reay 1991, Bogstad et al. 1994).

Atlantic cod diet generally reflects prey availability. The degree of spatio-temporal overlap between cod and its prey is reflected in the diet. In this sense cod are opportunistic feeders. Changes in the prey field between geographic regions or across time are gener- 


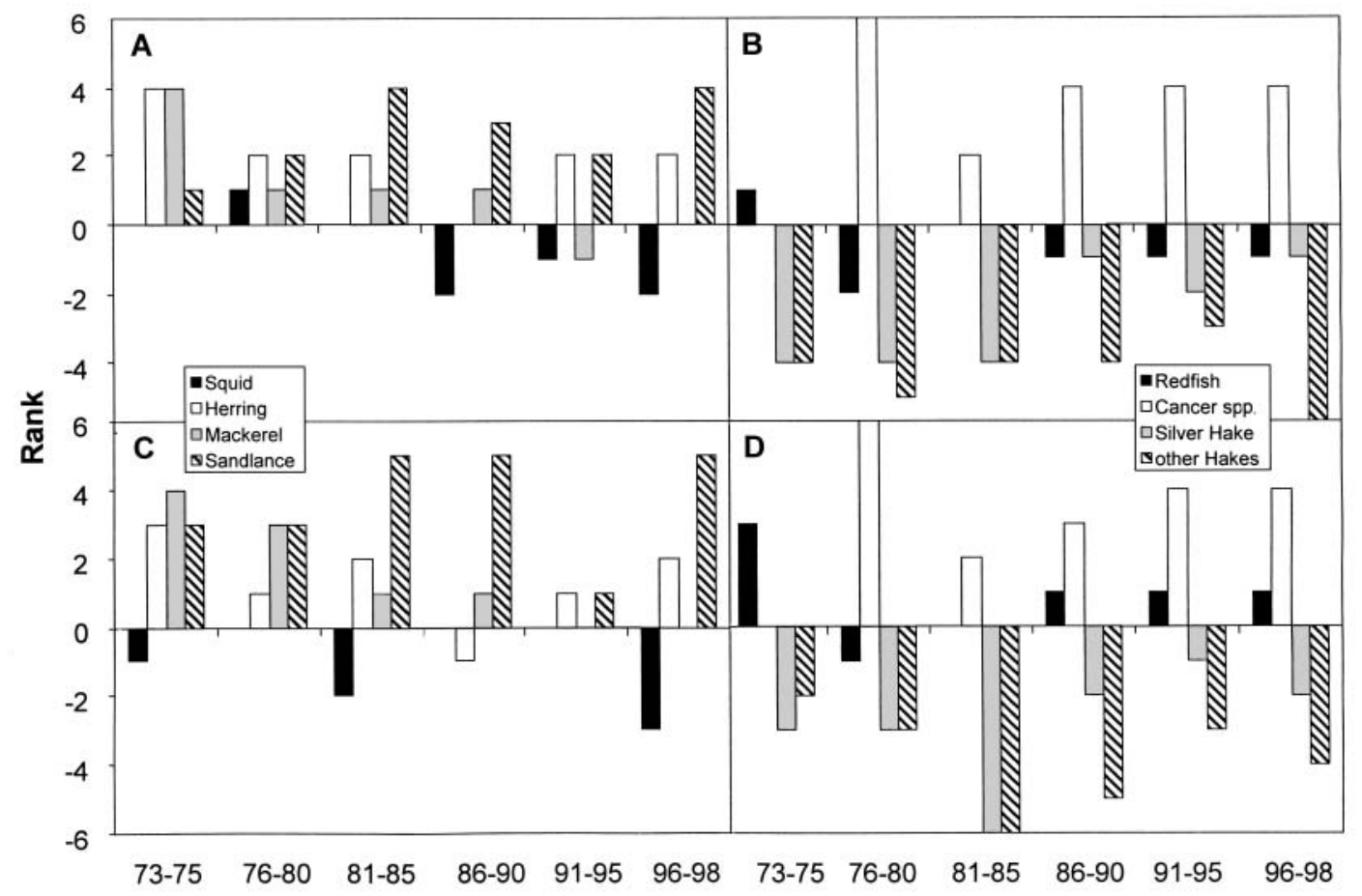

Fig. 14. Gadus morhua. Difference in ranks of frequency of occurrence between cod stomachs and trawl tows. High positive values indicate preference, high negative values indicate avoidance, and values near zero indicate no preference. (A,B) Large cod contrasted with occurrence of prey in trawl. (C,D) Medium cod contrasted with occurrence of prey in trawl. 73-75 = 1973-1975 time block, $76-80=1976-1980$ time block, etc.

ally seen in the diet and have been similarly documented for other ecosystems (e.g. Konstantinov et al. 1985, Methven \& Piatt 1989, Lilly 1991, 1994, Sparholt 1991, Uzars 1994, Lee \& Khan 2000). For example, Lee \& Khan (2000) show a shift from fish to crustacean dominance in the diet of cod from south to north along the Labrador Coast, reflective of the distribution and abundance of capelin in the south and snow crabs in the north. In fact, cod have been used as a 'sampler' to assess the distribution, abundance and size structure of various prey species (Lilly \& Parsons 1991, Fahrig et al. 1993).

Although they are generalists, cod do exhibit distinct prey preferences. The consistently high preference index for sand lance, Atlantic herring, and Cancer spp. crabs across the time series are prime examples. These species may correspond to capelin, other crabs, sprat and other clupeids that comprise a large component of cod diet in other ecosystems (e.g. Lilly 1984, 1994, Grunwald \& Koester 1994, Hoines \& Bergstad 1999, Methven 1999, Lee \& Khan 2000). The differences in energy content among these prey items (Hislop et al. 1991, Kirsch et al. 1998, Lawson et al. 1998) may be one factor why they are preferred over others. In particular, herring and capelin have the highest energy density of a suite of northwest Atlantic species (Lawson et al.
1998). Conversely, the negative preference for silver and other hakes may be related to mutual predation by both species on juveniles of each other (Link 1999). It would appear that the primary search image of cod is for clupeid, crab and sand-lance-like prey. Other considerations such as prey detection, reaction, capture and ingestion are not fully understood for the entire suite of cod prey.

We view the major determinants of cod diet as a hierarchical sequence. First, cod size determines what can be eaten. Next is preference for specific prey. Third is the abundance of all possible prey, which leads to the consideration of spatio-temporal overlap between cod and all its possible prey. For example, if for whatever reason, herring on the northeast US continental shelf declined and were replaced in equal parts by sand lance and squid, we would expect the general diet of cod to reflect these changes in prey abundance and distribution as well as the preference of cod for these prey. In this particular example, we would expect the composition of herring in the diet to decline, squid to slightly increase, and sand lance to notably increase. Finally, other factors beyond the scope of this study (such as short-term physiology, spawning condition, localized oceanographic conditions or similarly scaled processes) may also influence cod diet. 
Commercially valuable invertebrates, particularly decapod crustaceans, are an important component of Atlantic cod diet, as demonstrated by the consistent amount of Cancer spp. crabs and pandalid shrimp in the diet. This finding is similar to other studies that document cod predation on crabs and shrimp (Lilly 1984, Lilly \& Parsons 1991, Robichaud et al. 1991, Fahrig et al. 1993), although the magnitude of predation by cod on lobster is negligible (Hanson \& Lanteigne 2000). Cephalopods also comprise a consistent part of cod diet. How the squid, crab, and shrimp fisheries in this region have influenced the abundance and distribution of these major prey species, and hence cod (particularly juvenile) feeding, remains an intriguing question.

Atlantic cod is also an important predator of many commercially valuable fish species. Species such as herring, mackerel, silver hake, other hakes and redfish are just a few of the finfish species consumed by this opportunistic predator. It is reasonably clear how fisheries for these other finfish species have influenced the abundance and distribution of the major fish prey of cod (e.g. Garrison \& Link 2000b). We recognize that when scaled by population level consumption, the importance of piscivory by cod has decreased in the northwest Atlantic ecosystem over time (Link \& Garrison 2002). Yet the potential for competition between cod and fisheries conducted on the finfish and invertebrate prey of cod, particularly at localized scales of concentrated cod abundance (Fig. 8), still exists and should be a consideration in the management of these fisheries.

Results concerning the impacts of cod predation on prey populations are ambiguous. Some studies have reported that cod can strongly influence and perhaps regulate prey population dynamics (e.g. Andersen \& Ursin 1977, Helgason \& Gislason 1979, Rudstam et al. 1994, Bogstad et al. 1997). Conversely, other studies demonstrate that while cod can consume a large amount of prey, some prey populations are not necessarily regulated by cod predation (e.g. Lilly 1991, Sparholt 1991, Hanson \& Lanteigne 2000, Overholtz et al. 2000). When a particular prey item becomes less abundant, cod switch to feed on more abundant alternative prey, thereby reducing predation pressure on the original prey species. Additionally, although fish still constitute a large amount of cod diet, the importance of cod as a fish predator in the Northwest Atlantic ecosystem has diminished in recent years. What was once the dominant piscivore now consumes $1 / 3$ of the biomass that it once did on Georges Bank (Link \& Garrison 2002). Finally, we observed persistently high population levels of several prey species even during periods of high cod abundance and consumption. Therefore, it is not likely that cod exert predatory control on all of its prey populations in the US northwest Atlantic.
Do differences in diet translate into broad impacts on cod populations? The evidence is unclear. Some studies indicate that a more 'balanced' diet, specific diet components, or simply more available food increase cod growth (Brown et al. 1989, Mehl \& Sunnana 1991, Jobling et al. 1994, Clark et al. 1995, Krohn et al. 1997, Lambert \& Dutil 1997, Dutil \& Lambert 2000). Other investigators indicate that spawning ceases or is curtailed if inadequate food is present (Kjesbu 1994, Burton et al. 1997, Lambert \& Dutil 2000). Lambert \& Dutil (1997) and Swain (1999) suggest that, combined with over-fishing, changes in cod diet are responsible for declines in cod stocks and distribution shifts. However, Lilly $(1991,1994)$ suggests that changes in cod distribution and inferred differences in growth rates at locales with different temperatures may not be related to changes in capelin distribution and abundance and, hence, the proportion they comprise of cod diet. Additionally, the growth and mean size of cod in the northeast US shelf ecosystem has remained relatively constant across time (Mayo et al. 1998, O'Brien 1999, O'Brien \& Munroe 2000), and the severe declines in cod abundance are primarily attributed to intense fishing pressure (Serchuk \& Wigley 1992, Serchuk et al. 1994, Murawski et al. 1997, Fogarty \& Murawski 1998). Whether food type or amount has influenced cod spawning, fecundity, juvenile survival, or recruitment in the northeast US continental shelf ecosystem is unknown. Thus, whether changes in trophic dynamics have broad implications for cod populations remains a key question.

Atlantic cod are representative of several other fish in the northeast US continental shelf ecosystem (Garrison \& Link 2000a). Many species are opportunistic generalists, exhibit ontogenetic shifts in diet, switch among prey according to prey availability and exhibit dietary preference for small pelagic fish. In contrast to other ecosystems, this ecosystem is a highly connected and complex food web with weak species interactions (Link 1999). Thus, it will be inherently difficult to predict community and ecosystem level responses to intense fisheries exploitation. Since cod is one of the major trophic pathways in this food web and has experienced a high degree of fishing pressure, this work represents another step towards further elucidation of the trophic linkages that determine ecosystem dynamics and responses to human perturbations.

Acknowledgements. We acknowledge the foresight and diligence of the present and past staff of the NEFSC in the planning and execution of the bottom trawl surveys. We thank the members of the Food Web Dynamics program, past and present, who were responsible for the collection, auditing, and management of the food habits database. In particular, we recognize the contributions of Cheryl Milliken, Karen Bolles, Richard Yetter, Brian Kaminer, Nancy McHugh, Rodney Roun- 
tree, William Michaels, Mike Fogarty, and Frank Almeida. Thorough and helpful reviews of the manuscript were provided by anonymous reviewers, Mike Fogarty, Ralph Mayo, Rich Langton, and Wendy Gabriel.

\section{LITERATURE CITED}

Andersen KP, Ursin E (1977) A multispecies extension to the Beverton and Holt theory of fishing, with accounts of phosphorous circulation and primary production. Medd Dan Fisk Havunders NY Ser 7:319-435

Azarovitz TR (1981) A brief historical review of the Woods Hole Laboratory trawl survey time series. In: Doubleday WG, Rivard D (eds) Bottom trawl surveys. Can Spec Pub Fish Aquat Sci 58:62-67

Bogstad B, Lilly GR, Mehl S, Palsson OK, Stefansson G (1994) Cannibalism and year-class strength in Atlantic cod (Gadus morhua L.) in Arcto-boreal ecosystems (Barents Sea, Iceland, and eastern Newfoundland). ICES Mar Sci Symp 198:576-599

Bogstad B, Hauge KH, Ulltang O (1997) MULTSPEC-a multi-species model for fish and marine mammals in the Barents Sea. J Northw Atl Fish Sci 22:317-341

Bowman RE (1981) Food of 10 species of northwest Atlantic juvenile groundfish. Fish Bull 79:200-206

Bowman RE, Michaels WL (1984) Food of seventeen species of northwest Atlantic fish. NOAA Tech Memo NMFSF/NEC-28

Brown JA, Pepin P, Methven DA, Somerton DC (1989) The feeding, growth and behaviour of juvenile cod, Gadus morhua L., in cold environments. J Fish Biol 35:373-380

Burton MPM, Penney RM, Biddiscombe S (1997) Time course of gametogenesis in northwest Atlantic cod (Gadus morhua). Can J Fish Aquat Sci 54(Suppl 1):122-131

Casas JM, Paz J (1994) Diet of Flemish Cap cod with particular reference to predation on redfish: 1988-1993. Sci Counc Res Doc NAFO 94-24

Clark DS, Brown JA, Goddard SJ, Moir J (1995) Activity and feeding behavior of Atlantic cod (Gadus morhua) in sea pens. Aquaculture 131:49-57

Clark SH, Brown BR (1977) Changes in biomass of fin fishes and squids from the Gulf of Maine to Cape Hatteras, 1963-1974, as determined from research vessel survey data. Fish Bull US 75:1-21

Collie JS, Tsou TS (1996) Multispecies virtual population analysis of the Georges Bank fish community. ICES Counc Meet Pap 1996/G:28

Daan N, Sissenwine MP (eds) (1991) Multispecies models relevant to management of living resources. ICES Mar Sci Symp 193

Durbin EG, Durbin AG, Langton RW, Bowman RE (1983) Stomach contents of silver hake, Merluccius bilinearis, and Atlantic cod, Gadus morhua, and estimation of their daily rations. Fish Bull US 81:437-454

Dutil JD, Lambert Y (2000) Natural mortality from poor condition in Atlantic cod (Gadus morhua). Can J Fish Aquat Sci 57:826-836

EPAP (Ecosystems Principles Advisory Panel) (1999) Ecosystem-based fishery management. National Marine Fisheries Service, Silver Spring, MD

Fahrig L, Lilly GR, Miller DS (1993) Predator stomachs as sampling tools for prey distribution: Atlantic cod (Gadus morhua) and capelin (Mallotus villosus). Can J Fish Aquat Sci 50:1541-1547

FAO (Food and Agriculture Organisation) (1998) The state of world fisheries and aquaculture 1998. FAO, Rome
Fogarty MJ, Murawski SA (1998) Large-scale disturbance and the structure of marine ecosystems: fishery impacts on Georges Bank. Ecol Appl 8(1):S6-S22

Garcia S, Newton C (1997) Current situation, trends, and prospects in world capture fisheries. In: Pikitch D, Huppert D, Sissenwine MP (eds) Global trends: fisheries management. Am Fish Soc Symp 20:3-27

Garrison LP, Link JS (2000a) Dietary guild structure of the fish community in the northeast United States continental shelf ecosystem. Mar Ecol Prog Ser 202:231-240

Garrison LP, Link JS (2000b) Fishing effects on spatial distribution and trophic guild structure of the fish community in the Georges Bank region. ICES J Mar Sci 57:723-730

Garrod DJ, Schumaker A (1994) North Atlantic cod: the broad canvas. ICES Mar Sci Symp 198:59-76

Grant SM, Brown JA (1998) Diel foraging cycles and interactions among juvenile Atlantic cod (Gadus morhua) at a nearshore site in Newfoundland. Can J Fish Aquat Sci 55: 1307-1316

Grunwald E, Koester F (1994) Feeding habits of Atlantic cod in West-Greenland waters. ICES Counc Meet Pap 1994/P:5

Hanson JM, Lanteigne M (2000) Evaluation of Atlantic cod predation on American lobster in the southern Gulf of St. Lawrence, with comments on other potential fish predators. Trans Am Fish Soc 129:13-29

Helgason T, Gislason H (1979) VPA-analysis with species interaction due to predation. ICES Counc Meet Pap 1979/G:52

Hislop JRG, Harris MP, Smith JGM (1991) Variation in the caloric value and total energy content of the lesser sandeel (Ammodytes marinus) and other fish preyed on by seabirds. J Zool 224:501-517

Hoines AS, Bergstad OA (1999) Resource sharing among cod, haddock, saithe and pollack on a herring spawning ground. J Fish Biol 55:1233-1257

Huessy K, St. John MA, Boettcher U (1997) Food resource utilization by juvenile Baltic cod Gadus morhua: a mechanism potentially influencing recruitment success at the demersal juvenile stage? Mar Ecol Prog Ser 155:199-208

Jakobsson J, Astthorsson OS, Beverton RJH, Bjornsson B, Daan N, Frank KT, Meincke J, Rothschild B, Sundby S, Tilseth S (eds) (1994) Cod and climate change. ICES Mar Sci Symp 198

Jennings S, Kaiser MJ (1998) The effects of fishing on marine ecosystems. Adv Mar Biol 34:203-352

Jensen AC (1972) The cod. Thomas Y. Crowell Co., New York

Jobling M, Meloey OH, dos Santos J, Christiansen B (1994) The compensatory growth response of the Atlantic cod: effects of nutritional history. Aquacult Int 2:75-90

Kirsch PE, Iverson SJ, Bowen WD, Kerr SR, Ackman RG (1998) Dietary effects on the fatty acid signature of whole Atlantic cod (Gadus morhua). Can J Fish Aquat Sci 55: 1378-1386

Kjesbu OS (1994) Time of start of spawning in Atlantic cod (Gadus morhua) females in relation to vitellogenic oocyte diameter, temperature, fish length and condition. J Fish Biol 45:719-735

Konstantinov KG, Turuk TN, Plekhanova NA (1985) Food links of some fishes and invertebrates on Flemish Cap. Sci Counc Stud NAFO 8:39-48

Krohn M, Reidy S, Kerr S (1997) Bioenergetic analysis of the effects of temperature and prey availability on growth and condition of northern cod (Gadus morhua). Can J Fish Aquat Sci 54(Suppl 1):113-121

Kurlansky M (1997) Cod: A biography of the fish that changed the world. Walker and Co., New York

Lambert Y, Dutil JD (1997) Condition and energy reserves of 
Atlantic cod (Gadus morhua) during the collapse of the northern Gulf of St. Lawrence stock. Can J Fish Aquat Sci 54:2388-2400

Lambert Y, Dutil JD (2000) Energetic consequences of reproduction in Atlantic cod (Gadus morhua) in relation to spawning level of somatic energy reserves. Can J Fish Aquat Sci 57:815-825

Langton RW (1982) Diet overlap between Atlantic cod, Gadus morhua, silver hake, Merluccius bilinearis, and fifteen other Northwest Atlantic finfish. Fish Bull 80:745-759

Langton RW, Bowman RE (1980) Food of fifteen northwest Atlantic gadiform fishes. NOAA Tech Rep NMFS-SSRF-740

Lawson JW, Magalhaes AM, Miller EH (1998) Important prey species of marine vertebrate predators in the northwest Atlantic: proximate composition and energy density. Mar Ecol Prog Ser 164:13-20

Lee EM, Khan RA (2000) Length-weight-age relationships, food, and parasites of Atlantic cod (Gadus morhua) off coastal Labrador within NAFO Divisions $2 \mathrm{H}$ and $2 \mathrm{~J}-3 \mathrm{~K}$. Fish Res 34:65-72

Lilly GR (1984) Predation by Atlantic cod on shrimp and crabs off northeastern Newfoundland in autumn of 1977-82. ICES Counc Meet Pap 1984/G:53

Lilly GR (1991) Interannual variability in predation by cod (Gadus morhua) on capelin (Mallotus villosus) and other prey off southern Labrador and northeastern Newfoundland. ICES Mar Sci Symp 193:133-146

Lilly GR (1994) Predation by Atlantic cod on capelin on the southern Labrador and northeast Newfoundland shelves during a period of changing spatial distributions. ICES Mar Sci Symp 198:600-611

Lilly GR, Parsons DG (1991) Distributional patterns of the northern shrimp (Pandalus borealis) in the Northwest Atlantic as inferred from stomach contents of cod (Gadus morhua). ICES Counc Meet Pap 1991/K:41

Link JS (1999) (Re)constructing food webs and managing fisheries. In: Boxter B (ed) Ecosystem considerations in fisheries management. Proc 16th Lowell Wakefield Fish Symp. AK-SG-99-01:571-588

Link JS, Almeida FP (2000) An overview and history of the food web dynamics program of the Northeast Fisheries Science Center, Woods Hole, Massachusetts. NOAA Tech Memo NMFS-NE-159

Link JS, Garrison LP (2002) Changes in piscivory associated with exploitation of the finfish community on Georges Bank. Fish Res 55:71-86

Lomond TM, Schneider DC, Methven DA (1998) Transition from pelagic to benthic prey for age group 0-1 Atlantic cod, Gadus morhua. Fish Bull 96:908-911

Manly BFJ (1997) Randomization, bootstrap, and monte carlo methods in biology. Chapman \& Hall, London

Manly BFJ, McDonald LL, Thomas DL (1993) Introduction to resource selection studies. Chapman \& Hall, New York

Mattson S (1990) Food and feeding habits of fish species over a sublittoral bottom in the northeast Atlantic. 1. Cod (Gadus morhua L.) (Gadidae). Sarsia 75:247-260

Mayo RK, O'Brien L, Wigley SE (1998) Assessment of the Gulf of Maine Atlantic cod stock for 1998. CRD 98-13, National Marine fisheries Service, North East Fisheries Science Centre, Woods Hole, MA

Mehl S, Sunnana K (1991) Changes in growth of northeast Arctic cod in relation to food consumption in 1984-1988. ICES Mar Sci Symp 193:109-112

Methven DA (1999) Annotated bibliography of demersal fish feeding with emphasis on selected studies from the Scotian Shelf and Grand Banks of the northwestern Atlantic. Can Tech Rep Fish Aquat Sci 2267
Methven DA, Piatt JF (1989) Seasonal and annual variation in the diet of Atlantic cod (Gadus morhua) in relation to the abundance of capelin (Mallotus villosus) off eastern Newfoundland, Canada. J Cons Ciem 45:223-225

Murawski SA, Maguire JJ, Mayo RK, Serchuk FM (1997) Groundfish stocks and the fishing industry. In: Boreman J, Nakashima BS, Wilson JA, Kendall RL (eds) Northwest Atlantic groundfish: perspectives on a fishery collapse. American Fisheries Society, Bethesda, MD

NEFC (Northeast Fisheries Center) (1988) An evaluation of the bottom trawl survey program of the Northeast Fisheries Science Center. NOAA Tech Memo NMFS-F/NEC-52

O'Brien L (1999) Factors influencing rates of maturation in the Georges Bank and Gulf of Maine Atlantic Cod stocks. J Northw Atl Fish Sci 25:179-203

O'Brien L, Munroe N (2000) Assessment of the Georges Bank Atlantic Cod stock for 2000. NEFSC CRD 00-17, National Marine fisheries Service, North East Fisheries Science Centre, Woods Hole, MA

Overholtz WJ, Link JS, Suslowicz LE (2000) The impact and implications of fish predation on pelagic fish and squid on the eastern USA shelf. ICES J Mar Sci 57:1147-1159

Palmer MW (1993) Putting things in even better order: the advantages of canonical correspondence analysis. Ecology 74:2215-2230

Palsson OK (1994) A review of the trophic interactions of cod stocks in the North Atlantic. ICES Mar Sci Symp 198:553-575

Robichaud DA, Elner RW, Bailey RFJ (1991) Differential selection of crab Chionoecetes opilio and Hyas spp. as prey by sympatric cod Gadus morhua and thorny skate Raja radiata. Fish Bull 89:669-680

Rudstam L, Aneer G, Hilden M (1994) Top-down control in the Baltic ecosystem. Dana 10:105-129

Serchuk FM, Wigley SE (1992) Assessment and management of the Georges Bank cod fishery: an historical review and evaluation. J Northw Atl Fish Sci 13:25-52

Serchuk FM, Grosslein MD, Lough RG, Mountain DG, O'Brien L (1994) Fishery and environmental factors affecting trends and fluctuations in the Georges Bank and Gulf of Maine Atlantic cod stocks: an overview. ICES Mar Sci Symp 198:77-109

Smith C, Reay P (1991) Cannibalism in teleost fish. Rev Fish Biol Fish 1:41-64

Sparholt H (1991) Multispecies assessment of Baltic fish stocks. ICES Mar Sci Symp 193:64-79

Strauss RE (1979) Reliability estimates for Ivlev's electivity index, the forage ratio, and a proposed linear index of food selection. Trans Am Fish Soc 108:344-352

Swain DP (1999) Changes in the distribution of Atlantic cod (Gadus morhua) in the southern Gulf of St. Lawrenceeffects of environmental change or change in environmental preferences? Fish Oceanogr 8:1-17

ter Braak CJF (1986) Canonical correspondence analysis: a new eigenvector technique for multivariate direct gradient analysis. Ecology 67:1167-1179

ter Braak CJF (1987) The analysis of vegetation-environment relationships by canonical correspondence analysis. Vegetatio 69:69-77

Uzars D (1994) Feeding of cod (Gadus morhua callarias L.) in the central Baltic in relation to environmental changes. ICES Mar Sci Symp 198:612-625

Vinogradov VI (1984) Food of silver hake, red hake and other fishes of Georges Bank and adjacent waters, 1968-74. Sci Counc Stud NAFO 7:87-94

Williamson CE (1993) Linking predation risk models with behavioral mechanisms: identifying population bottlenecks. Ecology 75:320-331

Submitted: December 10, 2000; Accepted: June 29, 2001

Proofs received from author(s): January 28, 2002 
